\title{
Legal Education, Legal Competence and Little Bo Peep
}

Professor Avrom Sherr, Institute of Advanced Legal Studies, University of London, England

Legal education is not a spectator sport. Discussions of legal education tend towards the political, the practical and the methodological and not towards the theoretical or the analytical. As a subject of study it is often thought of as weak, unrigorous or worse still "sociological". It somehow does not seem to have the power or the bite of substantive areas of law or of legal research.. This paper takes a small, but hopefully firm, step in the direction of change. The thesis argued is that University Legal Education at a time of enormous change in the legal profession and in legal education itself may have lost its way.

Whilst it was clear that legal education was really about preparing people for the legal profession, the mission of undergraduate legal education was more certain. Until a few years ago, just over $60 \%$ of law graduates went on to qualify for the profession. But of the 8,756 law graduates produced in 1995 only some 3,700 will find places to qualify as practising lawyers, other such places will be filled by non-lawyers. This represents about $42 \%$ of all law graduates. Overall therefore, training for the legal profession has become a minority interest for undergraduate teaching. It therefore becomes less obvious what needs to be taught in legal education and how it should be taught.

\section{The Relaxation of Professional Control}

Three different attempts were made in the decade leading up to 1995 to change the rules governing acceptance by the legal professions of "qualifying law degrees". In retrospect these changes appear as a progressive liberalisation of the ingredients of a qualifying law degree, but at the time, from the perspectives of the university law schools, negotiations seemed to be much more about issues of power and importance in the relationship between the professions and the university. In 1996, when ACLEC published its First Report on Legal Education, it proposed the ultimate liberalisation trusting universities to produce appropriate, and responsible courses, playing their proper role in the production of legal professionals. It remains to be seen whether this approach is accepted by the Law Society and the Bar Council.

It was not so much that the universities had won any battle, or war, with the professions. It was largely the question of numbers already mentioned. The professions must clearly become less able to exert their influence on the ingredients of a law degree when such a small proportion of law graduates can now proceed into practice.

One might have expected university law schools to be ecstatic at the likely prospect of a much more open regime. One might have hoped for the intellectual imagination to run free, for innovative programmes and approaches to begin to developed, for whole new areas of law to be opened up and for different law schools to characterise a range of different approaches to legal education. Interestingly, so far almost the reverse has occurred. University law schools have begun to look inwardly, in consideration of 
what ought to be the "core" of any law degree. Perhaps the two Funding Council processes of TQA and RAE (see below) have pushed law schools into a more standardised approach, conforming to a presumed understanding of what is necessary to succeed in the funding competition. Perhaps exciting and imaginative courses are assumed to be more expensive or just more awkward for already hard-worked educators bowing under the pressure of larger student numbers, less student certainty over careers, relatively poor salaries for the academic staff and the constant pressure to publish.

Legal education is progressively being "released" from the hegemony of the professional bodies. They are much less prescriptive about both content and method of undergraduate legal education and what constitutes a qualifying Law Degree. Indeed, in some cases the professional bodies have recently appeared to be more liberal than some of the University Law Schools themselves in their approach to teaching and assessment. But how should the universities act now? Having always been able just to react to the professional bodies, we will now have to think for ourselves.

A thousand different flowers are not ready to bloom and a whole set of new, untrammelled approaches, subjects, teaching systems, programmes, are not appearing.

Undergraduate legal education is beginning to look somewhat purposeless, or at least unclear of purpose. Little Bo Peep seems to have lost her sheep and does not know where to find them? Should the educators of undergraduate lawyers be looking towards the rest of the Academy for guidance? Should they be looking to the discipline of education more generally for guidance? Will they best be able to provide guidance for themselves from within? Or is the profession still an important model, lodestar, provider of meaning and generator of purpose.

This paper will consider each of these in turn in order to discover what messages each of them have for legal education, what value may already have been taken on board from each and plot the usefulness of each as a guide as to where to go in the future. And it will suggest one theme which may bring important elements of all of them together.

\section{The Academy}

What has law gained from the rest of the Academy? What is there yet to gain? And is it here that the law should look for its main guidance?

Much was happening within the university world during the last decade. There were pressures to take on much larger numbers of students into law schools, especially in the new university sector. With the collapse of the "binary divide" all Polytechnics became Universities. Many law departments had doubled their intake of students during the last decade whilst not making similar adjustments to numbers of staff, library facilities etc. At the same time the amount of money available in general to universities dropped considerably on a per capita basis. These changes would be bound to affect the learning environment. Although, in the event, they began to encourage greater student participation in learning, this would have to involve a smaller amount of staff time per student. 
In addition, new systems for quality assessment both of the research work carried out in universities (Research Assessment Exercise "RAE") and of the teaching (Teaching Quality Assessment "TQA"), provided new pressures. Although most law faculties would feel it was important to be seen as excellent teachers, the real money seemed to flow from the research assessment exercise. It is therefore possible that university law departments might have organised themselves for an optimal economic outcome. Good research would certainly feed into good teaching but, if lecturers devoted all their time to research and little time to student contact that might cause difficulty.

The effects of RAE and of TQA mean that imagination, variety, difference, are all subject to a process of standardisation, which is one of the more unfortunate effects of any quality assessment system. In order to produce an assessment of quality it is necessary to set a standard. It is therefore not surprising that marking people at such a standard and encouraging a standard should begin to provide more of a unitary measure and therefore more of a unitary result. Perhaps, then, the attempt of The Higher Education Funding Council for perfectly good reasons to achieve the raising of standards of teaching quality in higher education had some effect after all. Both Roger Brownsword and Tony Bradney have written critically on the nature of this effect within law. Dawn Oliver has also written on how a Law School might organise more positively to deal with these processes. Since the intention was to assess each law department against its own statement of objectives, the attempt was clearly made to allow for a plurality of approaches, something missed by many of the writers. Even so, the fact of assessment and any external influence would be likely to produce a narrower range of activity, as those assessed would be performing to a perceived set of expectations. These Funding Council initiatives have therefore had considerable effect on Law Schools as part of the University system.

Law Schools, Law Departments, Law Programmes, Law Institutes, Law Centres and Law Faculties, as they seem to be variously called (I will, if I may, refer to all of these together "Law Schools"), have never sat easily within the world of the rest of the Academy. Twining gloriously quotes Robert Maynard Hutchins, President of the University of Chicago, in his general view that a university is "an aggregation of sovereignties connected by a common heating plant". Experience of law within universities across the world shows an uneasy relationship based on a set of dichotomies. Law, for examples, considers itself "special". Other University Faculties consider law as "different".

In halls of Senates and university committees lawyers are considered nit-picking and sometimes unprincipled because they will argue both sides of a matter. Lawyers find others unanalytical, unobjective and scientists too right wing.

University administrators consider law as a low cost subject whose popularity can make it a money spinner. Law teachers on the other hand feel their students need more exposure to them, and therefore more money spent on staffing rather than less. The new movement towards skills teaching involves behavioural learning and assessment which cannot be done in large classes.

The culture of this academic tribe, Becher's concept, is also different. Traditionally lawyers have been inward looking, reductive in their thinking and concerned 
principally, if not only, with the internal discipline of arcane structures, ex-post facto rationalisations and the precedential weight of hoary judgements; in short with description of "detail" Academics in the humanities and social sciences are renewed by contact across disciplines, by the wider context of open discussion and the challenge of change and all that is new; with "overview". A course on the law of contract for example does not often start with the recognition that the contract is a system for organising the reliability of business or economic transfer. A course on contract begins with the detail of what constitutes offer and acceptance and ends with how to go about enforcement.

Lawyers are seen as narrow and sometimes as unchallenging, unenquiring and unimaginative. Scientists seem to see the lawyers as lacking in empiricism and their own brand of rationality. The world of law, fashioned as it is by lawyers and judges and drafters of legislation is seen as very different from the natural world of scientific study.

Of course, they all need lawyers. But they do not really want us as colleague academics. They want us as practitioners of the law. Educational academics, for example, want us to tell them about the new law of education, scientists want us to tell them about how to avoid copyright or health and safety problems. They want us; they see us, as practitioners and not as academics. This is, of course, also true of other "professional schools" such as medicine, accountancy, business and architecture as well. We are not alone in this, but it needs to be recognised. We can create legal knowledge but not a transportable discipline - we have more to learn from other disciplines to help us with our law than they can gain from the discipline of law as opposed to its content.

Can we be more like them? Can we learn from them? Do we want to? In a major study by Professor Phil Thomas of Cardiff he tracks the success of the socio-legal movement in the UK, by looking at its effect on law school courses and in research carried on by legal academics. Though few have been formally trained in socio-legal techniques it is clear that the study of law from the point of view of other disciplines has taken firm root, and has passed into mainstream legal subjects. This seems to be confirmed by Harris s and Jones.

In an article entitled "Law Schools Without Lawyers?" Professor Lilly goes further.He identifies three possible broad approaches to the study and teaching of law: the first approach concerns the practical or operational aspects of law; the second approach relates to the "doctrinal" which he says is analytical rigour applied in a legal context, searching for rules, rule systems and underlying principles in legal materials; the third approach to law is the "theoretical". He quotes Professor Judge Posner, perhaps the strongest of the law and economics writers in the United States in suggesting that the doctrinalists are being pushed from centre stage by "economic analysts of law, by other social scientists of law, by Bayesians, by philosophers of law, by critical legal scholars ... and critical race theorists, all deploying the tools of non-legal disciplines". And so, at least from the point of view of a doctrinalist, the success of the "theoretical" movement, by which he seems to mean openness to, and use of other disciplines, is considerable if not complete, within law teaching in the United States. 
Will Bo Peep then find her sheep this way? If she does, will they be the same sheep with which she left the meadow? Many of the benefits are well portrayed implicitly in Phil Thomas' work. What Professor Lilly seems to miss is that the good socio-legal scientist, the good critical lawyer, the good legal philosopher, critical race theorist etc. are all people who are good lawyers as well and perhaps as William Kunstler (the American Civil Liberties lawyer) once said "good lawyers first". They do not diminish law and the teaching of law by applying law to other disciplines or by applying other disciplines to law. On the contrary, they have the tremendous capacity to enrich law, its nature and the understanding of law among all law scholars, law students and the wider academic community.

So, if what the rest of the Academy has to offer is interdisciplinary studies there would seem to be some major advantages, although some might be concerned about the scale of such movements in recent years. If there are advantages, it is then sad that so many law faculties involved in undergraduate legal education still stick to themselves within the Academy, have their own libraries, for fear of contamination by other alien knowledge or disciplines; have their own buildings, refuse to be engaged in more general socio-legal institutional academic enterprise and in general declare their separation from the rest of the university.

Should we be there inside the Academy? Or should we simply be the trade schools for the profession? It could be said that accountants and medics do not necessarily show any better attitude to understanding the rest of the world outside of their own disciplines. Is this a problem of professional schools and not of the discipline of law itself?

It is interesting to compare our own with the system of legal education in continental Europe. Their systems are often said to be so much more fashioned to produce practising lawyers, judges and legal officials. They often have classes of thousands of students, perhaps three quarters of whom will never make it through all the examinations and graduate to become lawyers. Leo and Paul Torremans show how "supporting" courses in philosophy, psychology, sociology, economics, political and social history, epistemology, logic and ethics and language courses are all compulsory elements of the first two years of law study at Belgian Universities. According to Philip Leith, writing on "Legal Education in Germany" a full 31/2 months worth of courses must be taken from the Wahlfachgruppen, or electives including sociology of law, philosophy, criminology - although also included in this list is international law.

Perhaps more than medicine and accountancy, law has been able to stand outside and look at itself with the vantage points provided by cognate disciplines. Law schools, legal research and law teaching have all been immensely refreshed by this approach. The openness of fresh ideas have blown through the windows of law schools and scattered some of the growing moss and gathering dust that went with a Dickensian view of law. Any new vantage point is good, provided that the study is aimed at law, its nature, its effects, its practice, or its theory. And nobody seems to be claiming that the new theoreticians are not considering law itself. So questions of how far the pendulum has swung apart, one should applaud what has been gained from the rest of the Academy, even though it may often have been an uneasy relationship. 
Some sheep may be found here and brought home safely. Why not all? There are some limits to the theoretical perspectives of other disciplines. Each bring alternative, internally coherent, but competing viewpoints. But the nature of the "theory", as applied, is to provide a simplified, limited understanding which may not apply beyond the basic assumptions and language of each individual approach or context. So we must look elsewhere for the remainder of the sheep.

\section{Education}

What about the discipline of education specifically? Some law teachers have recently written that the main problems with legal education are that it is all about "legal" and not very much about "education". It does not take into account the major changes that have occurred in the discipline of education, in its theory and practice (see principally Fiona Cownie, Julian Webb, Julie Macfarlane).

A number of streams seem to have gathered together here at one confluence - teaching quality assessment and evaluation; legal skills; learning as opposed to teaching; formative assessment to promote learning; learning from experience; clarified learning objectives; learning outcomes; analysis of competencies; standardisation through learning and teaching standards; NVQ'ism and teaching design. Each of these merits specific treatment beyond the space available. But it is possible to say a few words about their joint effect on legal education.

Apart from Fiona Cownie's almost lone voice in this country, it has been the skills school largely which has promoted the educational discipline as a teaching approach. Academics and teachers interested in educating legal skills and promoting good lawyering behaviours such as Phil Jones, Julie McFarlane, Julian Webb have also promoted more of a competence based approach to teaching and assessment, looking at learning outcomes, objectively measurable systems of assessment, learning objectives, and all the other concepts and argot of the new educational theory. Many such theoreticians emanated from a background of degree standardisation that was part of the old polytechnic system, as Richard Grimes shows in his Research Report on "Legal Skills and Clinical Legal Education".

The need to provide standards within a more educationally professional approach, and especially objective standards, seems to me to be a statement about circumstances. It means that society feels it can no more rely on the individuals themselves or individual institutions, their education, training, ethos and system of socialisation to provide an appropriate level, but an outside body needs to assess and police this. Often a move to standardised assessment as under the old CNAA is the result of pressures on a system which otherwise would have been relied on to perform appropriately.

Movements towards standardised assessment have assisted this process of movement towards educational professionalism. It was already present to some extent in the university system through external examiners and possibility of monitoring by the Law Society Then, as already mentioned the Higher Education Funding Councils for England, Wales and Scotland decided upon both a teaching quality assessment and research assessment. The teaching quality assessment in particular attempted to utilise the new educational concepts of objectives, outcomes and competencies. 
Although the world of educational studies covers much more and perhaps more interesting, concepts, information and ideas, it has been these particular concepts of objectives, outcomes and competencies which have been taken to be important by those who have written within legal education about the discipline of education. Steve Nathanson's piece on the Culture of Design is an example of an attempt to push legal educators to think more rationally and carefully, more analytically and more imaginatively about the educational enterprise in which they are involved, along the lines shown to us by the educationalists.

The question is: is this useful? Will Bo Peep find the rest of her sheep easily in this way. Will the tide of the new educational philosophy bring them home, carrying their tails behind them, without law schools needing to do anything?

I wish to make some personal comments in a carefully measured way about the skills and competencies and learning outcomes approach. Although what I am about to say is probably true for other disciplines as well, I believe it to be more so for work within professional disciplines. An outcomes or competencies based approach is useful, but it is only so useful. We must actively seize the opportunity this approach provides of beginning to analyse whole areas of information, and understanding where the elements of such analysis are beginning to be available. We must take upon ourselves, as researchers and teachers, the beginnings of this job of observing carefully what is involved in what we are trying to teach law students and how we would like them to end up.

On the other hand, it is absolutely clear that this work is endless and will never be complete or absolute. Progression (including within my own work) is often by wave upon wave of reductive lists of skills. There is only a certain amount of information or analysis which can be reduced to an outcomes or competencies basis and be measured as such. Professor Twining's upcoming review of Le Brun and Johnstone states this in a rather nice way. He says learning outcomes are "all fine, provided you don't actually believe in them".

Both sides of this argument seem to me to be correct. The job has to be done. The work of understanding what it is we are trying to teach, has to be progressed and made more and more complete. This is a job which is worth doing and one to which I have devoted some considerable time. It is worth doing because it tells us more and more about the subject we describe and therefore more and more about what we are aiming to teach. On the other hand, there will always be something missing - which will defy this "bureaucratic rationalist" approach as Twining calls it.

I do not think that it is elitist to say that there are elements of the work of law which will be too difficult to render down into a set of simple, objective statements against which we can then measure our students. Law is complex, it exists in a "real" world with all the complexities that brings and it is not susceptible in its entirety to the minimalistic NVQ'ism which is currently being forced upon it. I believe this to be true in relation to the vocational stage and beyond, but also in relation to the effect this approach is having on the undergraduate sector. 
I find it worrying because I believe it is necessary to form the analysis, the analysis should then inform our teaching and assessment. BUT this will be insufficient to measure the performance of students or legal work beyond a basic threshold of competence. In addition, such standards often seem to be used only as a reactive and backward looking process. Teaching and research should be capable of being transformative and developmental; involving an implicit critique of historical norms and enabling not just "understanding" but also change where necessary. Any attempt to press ahead with the NVQ approach beyond the lower levels of understanding of what is involved in law and legal work will not be either useful or effective. Although it may appear as if a system of assessment has been set up and that an accommodation of interests has been reached between jobless law graduates and the organised legal profession. The pressure for this, which seems to be coming from parts of the Law Society and supported by some items within ACLEC's First Report on Legal Education, seems intended to produce a form of para-legal underclass, to carry out the repetitive work of law, at a lower cost; thereby employing the ranks of law graduates who have not been able to obtain pupillage or training places - but not giving them the qualification or wage packet of fully fledged lawyers.

This pressure has also been bolstered by the circumstances of the sudden growth in the numbers of skills teachers at the vocational stage, generated by the new vocational courses - BVC and LPC. Almost overnight a large cadre of skills teachers had to be created to perform this function. Previously, skills teachers had come from the ranks of clinicians. Their approach was born of the need to create law students who could carry out legal work for the poor with minimal experience. They intended to promote in their students the ethics of care and understanding of their client community. Teaching legal skills was part of an holistic, caring approach to legal work, not a routinised, sanitised set of statements on a sheet of A4. It was not possible to recreate the strength, the caring warmth and other effects of the clinical movement, or even, some would say, good skills teachers, in such a short time. We seem to have retained the form, but not the content, or the feeling, or the learning environment of experience of the real client. This has affected undergraduate legal education also by presenting poor models of skills and what skills teaching has to offer.

So, there seem to be dangers as well as major advantages in looking for guidance from this area of the discipline of education. It must be useful to be more analytical about what we teach, to be more purposeful, more clear and more objective in the manner in which we assess our students. But, none of this needs to lead to an obsessive reductionism or an uncritical approach to what we analyse, or to a belief that all we can analyse today is all that is there. And it should not blind us to all the good things we can also learn from the discipline of education: including learning from experience, about techniques in adult learning, student centred learning, the sociology of education and much more. A blind following of learning outcome measurement as a new holy grail is probably not among these. Bo Peep must be careful about finding these sheep - they might all end up looking rather like Dolly the clone.

\section{Law Schools - Navel Contemplation}

Should law schools look inwardly to themselves for direction? Should law schools relax in the expectation that they can find their guidance at home because the nursery 
rhyme says the sheep will return their without assistance. This form of navel contemplation will not for everyone be useful, attractive or elegant. Experience of some very different law schools suggests that some may profitably look within for the range of knowledge, information, approaches, methods, subject areas, experience that is really necessary in order to consider future planning. But others would implode. Tearing each other to bits, arguing over a constantly decreasing cake has already become the pattern of the last five years. The changes which will affect the future of law, the future of the legal profession and the future of legal education are not, or not only, held within the law school and its library. If we wish to study and understand these we must do more than look inwardly. And if we only look inwardly we will fail to understand the dimensions and nature of change and its impact on what we do. The message which lay behind Professor Hepple's Inaugural Lecture in Cambridge last year, "trust the universities" must mean trust them to make the right decisions and in the right way. If all it means is allowing law teachers to do what they want to do, or get involved in massive internal wrangles, this will not be enough.

So what can the law schools do by looking within? One thing they can do, which was a part of what occurred during the Funding Council Teaching Quality Assessment Exercise, is to look within for examples of all that is best about legal education. Excellent teaching, imaginative ideas and positive learning are, at this moment, a part of what is happening in a law school around the corner. But what law teacher would dream of walking in on someone else's lecture to see how they performed. This does sometimes occur as a policing mechanism to check on people applying for what used to be tenure or senior lectureships, if not higher. But it is surely something that law teachers should, in general, do to learn how to be a law teacher. More thought needs to be given on how to encourage discussion of such issues and opportunities for developing good models through mentoring systems and the like. There needs also to be occasions for appropriate encouragement of new ideas and the easy trial of new methods and approaches.

Steve Nathanson in his Sydney paper argues for a "culture of design" which allows these elements of good teaching to be accorded the same level of importance as other areas of research. A culture of educational design might mean that law teachers spend more time learning on the job, like professional practitioners nowadays in continuing education, about how best to perform their work of teaching. Lets send all the teachers back to school, within the school. It seems as if Dearing will be suggesting something like this anyway. But, it should not be organised as a disciplinary mechanism or as an assessment mechanism, but as a mechanism of mutual development. Both new and old teachers need continuing development. Such a system of mutual development might include groups of teachers in similar subject areas sitting in on each other's lectures, seminars, tutorials or workshops, discussing not only substantive issues, legal doctrine, multi-disciplinary approaches; but also ideas for getting across difficult concepts, for encouraging student learning and enabling and for freshening up their pedagogy. In this way looking inside the law school will be useful.

There are other things which need to be done inside the law school, but not just by learning from within. Information systems within the law school, which includes all of the library, CD-Roms, on line systems, the Internet etc, need to be thought through carefully and Information Technology needs to be properly financed. Lack of finance is by no means the fault of the law schools themselves. But lack of movement into an 
understanding of the new world of the law, perhaps that suggested by Professor Richard Susskind of Strathclyde University in his recent book "The Future of Law" is the fault of the Law Schools. I do not entirely agree with him about the way in which changes will take place, but that information technology will change the nature of law and the nature of the way lawyers practise I have no doubt. Understanding this first simply for the purposes of education and research is essential within the law school of the future, and it must come from within, assisted of course by the excellent work that Warwick University's CTI Law Technology Centre has done.

So Little Bo Peep may need to do some work to get those of her sheep at home into the right condition.

\section{The Legal Profession}

Where else can Little Bo Beep look? She can also look to the legal profession. She can clearly look there both in terms of the new systems of vocational training for the legal profession and in terms of the continuing legal education which now takes place there.

But, has this paper not now turned full circle? Isn't the profession itself as a system of training, and as a purpose for education, exactly what law teachers have been reacting against for so many years?

"Teachers in their turn grew tired of lecturing to empty benches, and tended to treat their educational function as a tiresome appendage to their practice, from which their livelihood was mainly derived. In a word teachers and students alike became content merely to go through the motions of observing the stringent and salutory medieval requirements"

These words are not a description of a modern legal education, although they could have been said about many a 1960s or 1970s law school. They in fact detail how the earlier system of legal education in the Inns of Court failed in the first part of the seventeenth century. The position which Hanbury describes is not the position now. In the 25 years since this author's undergraduate legal education, law teachers have become a profession of their own, as described by Rick Abel in his seminal work on the "Legal Profession of England and Wales". Work at the Bar, as the inevitable concomitant of a teaching post, has long disappeared. They were the bad old days when some teachers would only dash into the university for their lectures when the Cause List permitted. But, has anything been lost in this transition?

The propositions of modern university legal education that law is a science, as proposed by the Harvard Case Method, or that law is a social science as proposed by Yale are all reactions against a trade school approach. Should one agree with Lilly that we have gone too far towards the university? This author's position is that we have not gone far enough towards inter-disciplinary studies and we have not gone far enough towards "theory" and we have also not gone far enough towards understanding, analysing, developing and "forming" the legal profession. 
Looking to the legal profession both as a purpose, and for guidance, for legal education is quite clearly not a new idea. It lay behind the old Inns of Court system and is still the clear approach of the more "black letter" law schools

So, looking to the profession is largely what undergraduate legal education has done up until this time. In fact, the legal profession has all but designed the core of undergraduate programmes by defining the ingredients of a qualifying law degree, usually constituting over half of the syllabus. Professor Peter Birk's article in the Webb Journal on the permanence of the core complains that it will still be necessary to teach basic material at a very low level as a result of even the current system of proscription. But the release is much greater than he imagines. This is despite the now evident lack of monitoring confirmed by the Nick Saunder's article already mentioned. Despite also the slow relaxation of the rules themselves, the involvement of the professions, their ability to make decisions about what happens in university law schools, and the nature of those decisions and what they proscribe have all been the subject matter of more material written about English legal education than almost anything else. A good deal of it comes from Professor Birks himself, who feels very strongly about the CPE (the conversion course) which enables non lawyers to take a one year programme having obtained a non law degree in order to then qualify to do either a Bar Vocational Course or the Legal Practice Course for solicitors.

The Power of Professor Birk's invective is high. In his 1995 article in the Webb Journal of Current Legal Issues entitled, "Compulsory Subjects; Will the Seven Foundations ever crumble?", he says:

"... and the CPE conversion, which is tied to the compulsory list, opens the gates to floods of otherwise unemployable non-law graduates pouring in. "The Treasury interest is easy to read, as also that of the university bosses to whom legal education is a product which sometimes makes best profits downmarket. They have been very badly led".

The CPE, whose rules, syllabus and examination system are set by the professions, is in a sense a testing ground for what is absolutely essential to learn, in order to become a lawyer. The Birksian school considers this to be a possible, easy backdoor to studying law since many non lawyers will not have had to obtain the same high level of passes at ' $A$ ' level which are necessary to secure a place at university for the study of law. The CPE then, and the "law core", have been the major political battleground. But this does not answer the question "why did they need to be the major intellectual battleground for legal education?"

It is clear that they did not.

Perhaps it was because so much time and effort was spent in fighting the chimera of the dastardly legal professions who wished to control everything that the law schools did not really have enough time to think about the form or content of the intellectual pursuit which they would otherwise have preferred. Of course it is not true to say that no law schools thought about this. The University of Kent and the University of Warwick, followed by a number of others, made sounds long ago that they were unsatisfied not just about the political control but also about the subject matter. Somehow or other, agreements were reached by them with the professions and it did 
not seem to be a problem. It is only now that all the other law schools are released from these great bonds with which the profession bound them, that it is clear that, for the present at least, we have not yet developed a proper mind of our own.

It is suggested that there is another reason why the profession was able to dictate for so long and why the pattern of its dictation was so strongly adhered to. This thesis is fairly simple, and outside the enclosed world of legal education, it would obvious. The study of law is not the study of a naturally existing set of phenomena, but it is the study of what is legislated as law, what judges pronounce as law, what is practised as law, the effects of those laws and that practice and the context within which the law and its practice operates. I shall refer to all of these as "the work of law" since it deals with how law works and how law is worked.

It is argued first that law should be studied as a science or as a social science, but that study itself is still of those items just mentioned. It attempts to build an analysis and a rationality around, from, or within the vagaries of the "work of law". It can be quite distanced from the "work of law" in its standpoint, in its approach, and in the relaxation with which it contemplates the issues which hit lawyers at a fast rate in the vicissitudes of practice. But it is still studying the work of law. Whether it is statute or judge made law, it is a man or woman made product and how the men and women make that product is an essential element also of this study. It can be studied separately. It can be differentiated from the "pure science" but it cannot be ignored.

Secondly, most students who come to study law at universities, even if only $42 \%$ will make it into the practicing profession nowadays, usually still do so with one major purpose in mind. They want to study law. That includes what I have called "the work of law". Most of them actually do wish to become professional lawyer even though in the current economic climate they may not succeed. Some will become law teachers. Others will use their law in different ways, but still need to know about the work of law. Yet others still, probably a fairly small proportion of those who start off intending to study law, will study it without actually using it subsequently in the context of the world of knowledge or the world of work (if those are different).

The massive mismatch between the expectations and desires of law teachers and law students in the United States and in the UK as exposed by Macfarlane, Jeeves and Boon and more recently by Leighton, Mortimer and Whatley is based on this difficulty. Law students want to learn what will be useful to them, including knowledge for its own sake, including ethical approaches to law including the humanity of law, including socio-legal studies and including the work of law. Law teachers seem to feel that they need to react against this rather than using it as a driving force to motivate studies and courses and programmes and the work of individual students. Law students want to learn about law, and the work of law includes an understanding of the practice of law.

Therefore, it is suggested that the professions were able to proscribe not only because of the politics of the situation, but also because they deal with the work of the law which is a major subject of study in any law degree. It is not just the politics of control, but the inherent nature of the subject matter which reflects knowledge of what is happening in the world of the work of law. The challenge then of legal education is to harness the forces of the profession, the work of law and student interest and 
motivation all together to carry out the higher level of intellectual achievement which is essential for the production of better lawyers; by which I mean better academic lawyers, better practitioners, better judges, better prosecutors, better defence lawyers and better law students. Not to fight these interests but to harness them.

Academic colleagues should not misunderstand. This is not a sell out to the profession and professional bodies, but a recognition of what already is the basis of our subject matter and of student interest and student expectations. It does not assist us to get hot under the collar in ivory, redbrick, or even "60's brutalist" towers about the politics, for they seem to follow the reality.

Now that the law schools are almost released from this imagined hegemony we find ourselves about to self-impose something not too dissimilar. Many are saying if we do not have some guidance, some standards, some "core" how will we know what is a law degree and what is not? Now that we have that responsibility and do not find ourselves simply tilting at windmills elsewhere, we need to make some decisions which have to take into account some of the real issues involved in the work of law.

Not only is taking account of the concerns of the legal profession and legal professional work an appropriate approach for the reasons stated above, in developing legal education, but undergraduate legal education now has much to learn from the education and training that goes on at the vocational stage and for qualified lawyers. Two obvious elements which have already made their way up into undergraduate legal education are elements of skills teaching and workshop based teaching methods. Elsewhere I have expressed that there are limits to the current state of skills teaching in general, because it has been taken as a new orthodoxy which it is imagined can cover and control everything. Skills teaching is not the teaching or study of law, neither is it something that can be just picked up over a summers break. Nevertheless, as a pioneer of skills teaching within undergraduate legal education in this country I am convinced of the great worth of both this approach and the importance of the subject matter involved in understanding the work of law and in producing high quality lawyers: both professional and academic.

What then is the skills approach really about? It is a reaction to a previous system of legal education in which somebody entered the programme at age 18, went through three years of undergraduate legal education, one year of vocational course, and two years of articles (or one year of pupillage) without anybody articulating clearly what they were supposed to be taught and when. This author's own undergraduate legal education may serve as an example. We would learn the four subjects in the first year, the four subjects in the second year and the four subjects including perhaps a project in the third year. Nobody would conceptualise to students or at least openly articulate what the end product was supposed to be like, what sort of a law student or lawyer they wanted to end up with. All that was suggested was that we had to do certain subjects.

It became impossible to organise legal education on that basis when the amount of law pouring out of Parliament and the courts became too much to handle. At one point, nobody could from then on be well versed in the gamut of law. At that point it became essential to analyse not what subject matter was important but what concepts were important in law and what legal skills were necessary in order to deal with any 
subject matter which law could today, or in the future, provide. So, at the point where specialisation became essential for lawyers, so did conceptualisation and skills training become essential for legal education and law students.

"As the law became more complex... the final remnants of the mid-20th century notion that Law Schools could somehow teach in three years all the law a lawyer would need to know were reduced to ash. The emphasis of legal education...has finally and fully shifted to teaching fundamental legal principles and philosophies, perspectives on law's place in society and the thought processes and judgements inherent to lawyering. The intent is to graduate lawyers who will be capable and flexible learners and practitioners in a remarkably wide variety of settings".

Understanding the essential concepts leads to an understanding of what is essential about law and the work of law. Identifying essential elements, for the first time allowed the possibility of teaching those items directly, rather than imagining that they would happen to be there in the mind of the educational product, the law student, at the end of the period of legal education. So, "skills teaching" is the product of a rational analysis of what is essential to be learned, and then a direct form of teaching of what is found to be essential or of importance. This also explains the reason why skills teaching can never be everything that legal education is about. And it goes some way to explaining why competencies and learning outcomes can never be stated to an absolute finality. There will always be the ineffable, the indescribable, the uncapturable, that which is left to discretion. And such elements may not be capable of easy capture or easy reduction to simplified objective statement.

In fact, often what they will miss out will be what academics will consider to be "essence" or "crux"; that which drives intellectually a consideration of a subject area of a matter, of a problem or of a theory. It may well be that the element which is indescribable, will remain the major area of lawyer activity, when some of what is involved in practice will move to a de-skilled computerised function. So we must retain what is missing in a listed skills analysis and of course work to analyse it further but never expect to be able to reach the top of that mountain.

Skills, therefore have provided a healthy approach to clarity, effectiveness, certainty and objectivity in legal education across the board. They have coalesced some of the educational discipline approaches mentioned above and they have provided a new vantage point from which to review both teaching and the curriculum in the context of a vastly changing profession and body of law. But, most important of all, because of their provenance within professional legal studies they have brought into academic consciousness a contemplation of what is involved in the work of a lawyer and in the work of law. Thus they have provided a purpose, an approach, a methodology and also some subject matter for legal education in an area which was previously ignored as being to do with the business of practice rather than the work of law.

\section{Legal Competence}

If an overarching theme is necessary to be found for the purpose of legal education, a theme which can be looked for in all the places mentioned this evening, then legal competence might be such a theme. It is a theme that in the context of legal practice Professor Alan Paterson and this writer together with a team including Richard 
Moorhead, Lisa Webley, Tammy Goriely, Helen Micallef and others have been working on for the last eight years. It is also a theme which has also begun to guide legal education in the United States in the MacCrate Report on Bridging the Gap. Competence has been treated as an organising principle for legal education at all levels in the United States, in Australia and there is now interest in this both in Europe and elsewhere. Why "competence" as an organising principle? Does it not sound too much like all the things which have already been stated are useful provided you don't actually believe in them? Competence, but not necessarily competencies is useful because it has the ability to link all the different elements of legal education from the "nursery" stage of undergraduate legal education, onwards through the vocational stage and the post qualification stages. It is useful not only because it provides practical and intellectual coherence for an entire system, but also because it seems to transcend national and jurisdictional boundaries so as to allow easier transitions between, and harmonisations of, civil and common law approaches. As an overriding concept therefore it would allow easier migration of law between the European mainland and the UK.

It is also probably correct at about the necessary level for what might be needed in terms of standardisation of curricula, syllabuses and educational objectives as between different law schools which now seems to be the approach of the HEFCE Quality Assurance initiative, post Dearing. For, if there will be no core of legal subject matter which must be studied for a law degree, then there must be something like a set of legal concepts which are essential for the legal competence of our students at an appropriate level. Since we are talking about a basic level of standardisation, to replace a core, notions of legal competence will be sufficient to provide an appropriate level of expectation and therefore of organisation and assessment. Articulated notions made up of such legal competence may never, as already mentioned, cover the levels of excellence at each stage. But they will do enough to cover the equivalent of a basis, a core, and more. If notions of competence can begin to be articulated for the complexity of the world of legal practice as has started to occur in relation to legal aid franchising, then such notions can certainly begin to be articulated for undergraduate legal education, and already have been by Phil Jones and others.

If standards have to be articulated then competence appears to be a pretty good method of covering the basics. At the same time it does not do away with the more imaginative levels of higher intellectual thought, which can be operated differentially over a range of educational approaches and policies and subject matter in different institutions. By and large the literature of legal competence derives from literature on the profession. But that does not seem to be a good reason to reject it. Competence can provide an overarching set of values which can make links between different parts of legal education, but is not tied to singular methods of assessment and allows for more abstract, more subjective and more discretionary elements as well as a basic, objective standard.

What else has the profession shown us, or given us? Its system of continuing professional development (CPD), the continuation of vocational work into the Professional Skills Course, and the further continuation throughout practice life of continuing professional development have all been constructed as part of a system of lifetime learning, rather than a system of training and qualification in which 
everything is delivered at the beginning. Previously, everything had to be learned at University, at the vocational course, or during articles, since there was no formal training whatsoever afterwards. That presented a considerable amount of pressure for undergraduate legal education and for the vocational element. It could never hope to deliver a lifetime's worth of information, concepts, skills, approaches or ideas. Instead there was an assumed expectation that practitioners would learn from experience, and that learning from experience was bound to be beneficial.

Oscar Wilde, for example, says "Education is an admirable thing, but it is well to remember from time to time that nothing that is worth knowing can be taught". But, this is not so. In some research as yet unpublished, shown in relation to client interviewing that experience by itself is not a good educator. Often, if it teaches at all, it teaches badly. Many learn from watching others, or from the needs of practice, how to perform poorly. The old system of watching a more senior practitioner in articles could often have this affect. Even if the practitioner was good at his or her work, they may not have been a good teacher. Hence, the importance in this area of literature of the new concept of the "reflective" practitioner. This reflective practitioner of Donald Schön is the one who can best learn from experience during the normal period of apprenticeship and early work, i.e. whilst in circumstances of little formal training, or little monitoring accented to training, rather than the supervision of work.

But there are reasons why it is difficult to be a reflective practitioner, a good learner from experience. Legal practice is organised around the business of business, around the needs of making a living for those who work in the work of law, and for making profits for those who can. Legal Aid fees, at least when they rise at all, costs awarded by courts, fees for transactional deals all are now predicated upon a clarity that law is a business, and not an altruistic professional past-time for the good all rounder who happened to like standing on his or her hind legs in front of a bench. At a time when altruism could be afforded or considered in relation to client work, one supposes it may also have been considered in relation to the training of new lawyers in work. (Although intuitively one knows that training was much more haphazard then). Now, the vicissitudes of practice do not allow for time for each person to think, reflect and learn from each experience they have. In fact the driving power of the taxi meter and the need to produce a product at a reasonable cost makes this reflection all the harder. So a system of lifelong learning such as CPD enables the possibility of a more formal reflection to occur in the context of a learning environment, whilst inside practice. The business jargon of the "learning corporation" is obviously a very similar concept. We are importing it late into law.

How does this leave the law school? Until this point this paper refers, to legal education only as meaning what goes on in the undergraduate law school. Professor Twining refers to this as the "nursery years" and the primary school approach - a part excuse for my use of a nursery rhyme character to portray the problems of undergraduate legal education, in its search for meaning and purpose. Legal education is of the nursery variety in this country, because our students, unlike those in North America and parts of Europe do not take another undergraduate degree before they move on to study law. Even in the United States where lawyers are postgraduates Rosato suggests in the title to a piece on gaming techniques in the law school classroom, 
"All I ever needed to know about teaching law school, I learned teaching Kindergarten: introducing gaming techniques into the law school classroom".

But it is also "nursery education" because university law schools have not faced up to an understanding of what a new system or approach to learning - life long learning will mean to them. This is not just a release from the pressure of having to provide everything at one go, right at the beginning of someone's career, to last them for the next 40 years. It is also a major opportunity to be involved in the continuing learning that must occur in the life of each law practitioner. Practice needs the academy far beyond the nursery stage. The links which occur in North America at the higher level between the profession and the academy, between the bench and the academy and the easier movement between all of these are essential features also to be fostered in the UK.

In summary, undergraduate law schools need to take some lead from the profession in terms of organising the future of legal education. This means adopting some of the new techniques and approaches which professional legal education has adopted. It also means taking account of the changes in professional legal education and training and continuing legal education, in order to know what to teach and how to teach at the undergraduate level. But, it also means that law schools should take account of their important role as the possible providers of legal education from the cradle to the grave This might equate with Twining's ILC or International Legal Centre. This is not because law schools should have their snouts in the training trough, although such funding will undoubtedly be useful, but because the profession actually needs the overview, the distance, the perspective, the dispassionate observation, the brain power and the teaching ability which, as a package, only the law schools can provide.

If this is correct, why has it not happened yet? There are some 65,000 practising solicitors who will all by November 1998 need 16 hours of compulsory continuing legal education a year. About half of these numbers are currently involved in continuing legal education. This will occur throughout the country in the midst, perhaps, of the greatest changes ever in organisation, management and subject matter of the legal profession. How is it that the law schools are not already providing this service and from doing so, learning more, at least as much as the profession can provide, about the work of law? The roots of this problem lie deep. The profession distrusts the universities, as being full of myopic individuals without an understanding of life in the real world. The law schools and the academy distrust the profession as a group of financially motivated entrepreneurs who have little interest in anything of intellectual value especially if it makes no money.

Each is secretly a little jealous of the other and would quite like either more serious intellectual inquiry plus a little more freedom, or the importance of client responsibility and a little more money. From having existed in both worlds it is possible to say that the people in each are not as different as they think, in general, from the people in the other. As subjects become more interdisciplinary and as academics seek to learn more about the context and more about the socio-legal study of the areas in which legal work is carried out and of the work which lawyers do, there is more need of contact for the purposes of both research and teaching between academics and practitioners at all levels. Being involved in training will provide that link and research opportunities which the academic world needs and the training 
opportunities which the practitioner world needs. As the most senior tranche of practitioners comes on stream into CPD by November 1998, a group whose memories of legal education might have faded, but which is strongly tied in to the university model, this is a time to be seized by both.

Perhaps the rest of the sheep have been found. But what else can a long look towards the legal profession provide. It is suggested that it will provide a completely new model of practice for which the new generation of lawyers will need to be educated. This writer is currently in the process of completing the second edition of a book on Client Interviewing and Client Handling. Considering what was necessary to put in the new edition written 10 years after the first, it is clear that a completely new approach to this area of legal work had to be considered. The first edition seemed to be written with the basic assumption that each client's matter, or file, or case, would be looked after by the same lawyer from the first interview and taking instructions, all the way through until the final disposition of the case. Ten years on this is no more the predominant model of legal services delivery. Elsewhere, and in a previous Inaugural Lecture and this has been discussed. Industrialisation, de-professionalisation and deskilling have come to the work of law. One takes little joy in the realisation of this prediction. But since it has now happened, it has been necessary to write an extra chapter for the Client Interviewing book to try to cover this changing model. Though there may well have been a lot wrong with Dickensian lawyering and with the Soames Forsyte character of Galsworthy, fossilised management structures, poor accounting and little service in some parts of the world of solicitors, it is still sad that legal work will be broken up in this way. But law is no different from banking, medicine, accountancy, architecture, or other professions. Work is differentiated and devolved down to the lowest possible category of person and moved between different individuals at different times.

One can see how this might tie in well with approaches to life long learning within the profession and development over a longer period than just the university years. But legal education for the future must take into account what difference this may mean, or should mean, to the way in which lawyers are taught and the work of law is studied.

If this is correct about the work of client interviewing, then it must also be correct about every other element of the work of law.

As the model of legal work is different, so will legal education for legal work need to be different. Suskind's view and the view of Professor Barry Dean of Linklaters and Paines and of the College of Law, is that these differentiated tasks will be organised as tasks at that level for each lawyer almost for life. So, for example one person will do the interviewing, or the "intake" of clients, another one will do the drafting of contracts, yet another do the drafting of pleadings, yet another do the negotiation, yet another do the advocacy etc. There will be some lawyers who will be information officers and some lawyers who will draft the firm's precedents. There will be others who amend the precedents and yet others who use them.

Although this author's vision, or nightmare, of legal work is not very different from this, and some firms are already quite far down this road, there is one major disagreement with Barry Dean on career progression. It is suggested that different 
lawyers will carry out these different activities at different stages in their practice lives and their legal development. So some people may move to work as drafters of precedent or legal information officers for a period and then move back to an area of client work and perhaps onwards to another area of management and so on.

Apparently this is a model which Japanese companies use for their young executives, and one which Charles Handy mentions in the "Age of Unreason". It is suggested that this will become essential since the specialisation involved in the legal work, which is necessary for other reasons, will lead to lack of variety, by definition, and therefore a lack of job satisfaction unless a system of this nature evolves.

So this will provide quite a new job for legal education. There will need to be a new vision and a major problem in conceptualisation of how to prepare, educate and train people for the new world of the work of law. This is a difficult enough issue to take over to another paper, but it is one of which all parts of legal education and training must now take clear account.

\section{Little Bo Peep}

There are five stanzas in the Little Bo Peep nursery rhyme and it may be worthwhile to be reminded of them. They are pretty strange and full of seeming nonsense, vague allusion, or some arcane symbolism which might be useful within feminist literature. Despite considerable research no satisfactory explanation has been found for this peculiar story and its meaning.

Bo loses her sheep in the first stanza but is reassured that if she does nothing they will come home "wagging their tails behind them". Lulled into this false sense of security, Bo falls asleep and dreams the return of her sheep, her purpose; but she wakes to find them still gone. So, belatedly in the third stanza she does something active, picks up her crook in a determined search, one that is successful because the sheep are found, but unfortunately they are already damaged. They have no tails. Subsequently, she finds these amputated limbs, rather like a set of NVQ statements, hung out on a tree to dry.

This seems to relieve her anxiety and in a deft act of what must by that stage have been limb transplant surgery, tries to repair the damage.

If legal education is in the doldrums, at a crossroads, lost its way, lost its purpose, then it should not be too relaxed about this and about the consequences. Legal educators, should not fall asleep on the job, lulled into a false sense of security, the damage that could be done to legal education might be beyond repair.

This paper has set out four different places like the four subsequent stanzas where a sense of purpose might be found. Each is important, each is relevant, each is useful and each also has its dangers. Among these the legal profession has been privileged as a purpose guide because legal educators ignore it at their peril. Academic colleagues should not misunderstand, it is not suggested that the tail should wag the sheep.

So why Little Bo Peep? Twining's allusion to the "nursery years" of undergraduate legal educationis mentioned above. "The Annotated Mother Goose" by William Baring Gould details the first publication of this nursery rhyme in 1810 in the third 
edition of a volume called "Gammer Gurton's Garland, or the Nursery Parnassus, A Choice Collection Of Pretty Songs And Verses For The Amusement Of All Little Good Children Who Can Neither Read Nor Run".

The Annotated Mother Goose remarks:

"It is rather surprising that this, one of the most popular of all Mother Goose rhymes, does not have a longer history. Try as scholars will they cannot, to this day, find an earlier printed version of Little Bo Peep than that in Gammer Girton's Garland edition of 1810".

The first edition of Gammer Girton's Garland was brought together by Joseph Ritson, who was born in 1752 in Stockton Upton Tees, Durham and "was bred to the legal profession" but seemed to prefer the life of English Literature. So, a lawyer at least brought together the first two editions of this set of nursery rhymes that eventually included Little Bo Peep, clearly an important part of his legal education.

\section{Equality of Opportunity}

Oscar Wilde began this paper, is mentioned in the middle, and perhaps should end it;

"...in England, at any rate, education produces no effect whatsoever. If it did, it would prove a serious danger to the upper classes, and would probably lead to acts of violence in Grosvenor Square".

Apart from the other issues raised one, other is more crucial and more pressing but needs a long term solution. Whatever the approach legal education takes, it must evince a fairness that can then be expected from the lawyers it educates and forms. Equality of opportunity has not yet been reached in entrance to the legal profession. The most recent report of the Law Society funded cohort study clearly states that racial discrimination is still occurring in different parts of the system of qualification as a lawyer. It goes on to say that there are very clear indications that class, social background, is of equal influence. A major effect of the great changes that have occurred in the system of legal education has been the incredible rise in costs for those who are not subsidised by large commercial firms.

If an answer is not found to this we will not only be proving how true Oscar Wilde is about English society over a hundred years later, we will also be ensuring that there are no lawyers to deal with the work of the individual, and especially the less privileged individual who needs support from and against the State. In the new world of a new government, we must make immediate efforts to change this position so that law will never again be simply the preserve of large commercial interests or the wealthy. 